\title{
RELATIONSHIP RISK-RETURN OF NATIVE SPECIES SAWN WOOD IN THE STATE OF PARÁ, BRAZIL 2003-2007
}

Rommel Noce' ${ }^{1}$, Márcio Lopes da Silva², Lourival Marin Mendes ${ }^{3}$, Agostinho Lopes de Souza² ${ }^{2}$ José Luiz Pereira de Rezende $^{4}$, Rosa Maria Miranda Armond Carvalho ${ }^{5}$, Juliana Lorensi do Canto ${ }^{6}$, Juliana Mendes de Oliveira ${ }^{7}$

(received: September 4, 2008; accepted: March 31, 2010 )

\begin{abstract}
This study characterized the risk-return relationship of sawn wood of different native forest species of the Amazonian area. Specifically, it was determined the risk-return relationship of Ipê, Jatobá, Maçaranduba, Angelim Pedra, Angelim Vermelho and Cumaru boards, in 2003-2007 period. The Geometric Growth Rate of prices of the $\mathrm{m}^{3}$ of boards of each species was admitted as return estimative and the variation coefficient as indicative of risk; the estimated values were plotted in dispersion graphics allowing graphic analysis. It was noticed that their prices float, relatively, in the same way and that Jatobá stands out in attractiveness terms, considering the whole period while the other species presented a coherent relationship among themselves i.e., higher returns associated with high risks. Angelim Vermelho and Maçaranduba stood out for the attractiveness, in an annual perspective.
\end{abstract}

Key words: Forest economy, native tree species, attractiveness.

\section{RELAÇÃO RISCO-RETORNO DE MADEIRA SERRADA DE ESPÉCIES NATIVAS NO ESTADO DO PARÁ, BRASIL 2003-2007}

\begin{abstract}
RESUMO: Este estudo caracterizou a relação risco-retorno da madeira serrada oriunda de diferentes espécies florestais nativas da região amazônica. Especificamente, determinou-se a relação risco-retorno das pranchas de Ipê, Jatobá, Maçaranduba, Angelim Pedra, Angelim Vermelho e Cumaru observada de 2003 a 2007. Admitiu-se a taxa geométrica de crescimento dos preços do $m^{3}$ das pranchas de cada espécie como estimativa de retorno e o coeficiente de variação como indicativo do risco e os valores estimados foram plotados em gráficos de dispersão, permitindo análise gráfica. Concluiu-se que os mesmos flutuam de forma relativamente semelhante e que o Jatobá destacou-se em termos de atratividade, considerando todo o período, enquanto as demais espécies apresentaram uma relação coerente, entre si, de maiores retornos acompanhados de maiores riscos. O Angelim Vermelho e a Maçaranduba destacaram-se pela atratividade numa perspectiva anual.
\end{abstract}

Palavras-chave: Economia florestal, espécies arbóreas nativas, atratividade.

\section{INTRODUCTION}

High concentration and inequality in sawn wood domestic market was observed, both for conifers and for evergreen forest tree species, in the last years of the of 90's decade. Characterizing this market as oligopoly, which could harm the efficient allocation of resources (NOCE et al., 2005a).
The reduction of the volume of world trade of sawn wood did not favor the increase of exports in this period. Internal factors as cost, productive system, product quality and exchange rate, allowed Brazil to show competitiveness in this economic scenery (NOCE et al., 2003).

The economical agents operate in a volatile atmosphere due to globalization, exchange rate flotation and

\footnotetext{
${ }^{1}$ Administrator, DS in Forest Science, Professor - Instituto de Biodiversidade e Florestas - Universidade Federal do Oeste do Pará/UFOPA - 68035-110 - Santarém, PA - rommelnoce@yahoo.com.br

${ }^{2}$ Forest Engineer, DS in Forest Science - Departamento de Engenharia Florestal/DEF - Universidade Federal de Viçosa/UFV - 36570-000 Viçosa, MG - marlosil@ufv.br, alsouza@ufv.br

${ }^{3}$ Forest Engineer, DS in Forest Engineering - Departamento de Ciências Florestais/DCF - Universidade Federal de Lavras/UFLA - Cx. P. 3037 - 37200-000 - Lavras, MG - lourival@dcf.ufla.br

${ }^{4}$ Forest Engineer, DS in Forest Economic - Departamento de Ciências Florestais/DCF - Universidade Federal de Lavras/UFLA - Cx. P. 3037 37200-000 - Lavras, MG - jlprezen@dcf.ufla.br

${ }^{5}$ Administrator, DS in Forest Science - Departamento de Engenharia Florestal/DEF - Universidade Federal de Viçosa/UFV - 36570-000 Viçosa, MG - rosamaria@ homenet.com.br

${ }^{6}$ Forest Engineer, DS Candidate in Forest Science - Departamento de Engenharia Florestal/DEF - Universidade Federal de Viçosa/UFV 36570-000 - Viçosa, MG - jlcanto@terra.com.br

${ }^{7}$ Architect, DS Candidate in Wood Science and Technology - Departamento de Ciências Florestais/DCF - Universidade Federal de Lavras/UFLA - Cx. P. 3037 37200-000 - Lavras, MG - julianameoli@yahoo.com.br
}

Cerne, Lavras, v. 16, n. 2, p. 199-207, abr./jun. 2010 
alterations in the technological park, motivating, therefore, risk evaluation (LEMGRUBER \& OHANIAN, 1997).

The risk represents, in the fundamental sense, the possibility of the variability of returns, associated to the assets that may cause financial damage. The risk-profit relationship plays a preponderant role in the determination of the destiny given to the private capital. The coherence of this relationship is the main attractiveness of private investment. The expectation, in a general way, is that higher risk levels are associated to higher returns (GITMAN, 2004).

The risk-return relationship of sawn wood deteriorated along the eighties, recovering in the nineties. Presenting, however, coherent behavior, both for 80's and 90's decade, characterizing the wood exploitation as attractive to private capital (NOCE et al., 2005b).

The analysis of prices and risks behavior contribute, both for the quality of decision making of the economic agents' and for the diagnosis of future sceneries (BURATTO, 2005; CASTRO et al., 2007), as for the development of politics envisaging the preservation of the forest resources. This may also indicate the attractiveness of investment on forest species to private capital. This research tries to clarify the understanding and the rationalization of lumberman's economic decision making, in the Amazonian area.

Species which presents coherent relations of riskreturn will be attractive to private investment in their exploitation, highlighting both the possibility of business presence in the forest management and predatory exploitation form in the absence of control mechanisms.

This study, therefore, aimed to characterize the riskreturn relationship of sawn wood of different native forest species of the Amazonian area. Specifically, it was looked for determining the risk-return relationship of Ipê, Jatobá, Maçaranduba, Angelim Pedra, Angelim Vermelho and Cumaru boards, in 2003-2007 period.

\section{MATERIALS AND METHODS}

Starting from Pará State, on going prices of native species wood board, a historical monthly price series were generated for the species Ipê, Jatobá, Maçaranduba, Angelim Pedra, Angelim Vermelho and Cumaru tree species. The wood price series were corrected by IPA (Wholesale Price Index), for the period of January 2003 to December 2007. The wood price are available in the Center of Advanced Studies in Applied Economy - CEPEA (2008), and the IPA is available in Institute of Applied Economical Research - IPEA (2008). The original IPA price series (base
January $1994=100$ ) was previously transposed base December $2007=100$, to the treatment of the price series.

The corrected price series were graphically expressed in a way to evidence the behavior of the sawn wood real prices of the different species. TGC (Rate of Geometric Growth) and CV (Coefficient of Variation) were calculated for the representative price series, of each tree species.

Through the elaboration of dispersion graphics, the risk-return relationship was described among the wood of the different species, for each year of 2003-2007 period. Later, it was demonstrated and discussed the evolution of the risk-return relationship of each species, in the studied period.

It was admitted that $T G C$ and $C V$ are good proxies for return expectation and associated risk, respectively (CONTADOR \& SILVA, 1992). This procedure had already been employed in the forest area, allowing to verify that the risk-return relationship of sawn wood was coherent during the 80's and 90's decades. This fact allowed investment in wood exploitation to be seen as attractive in the period (NOCE et al., 2005a). This technique, when applied to other forest products, also generated consistent results, e.g. was the case of natural latex, on which was possible to forecast that investment on it was unfavorable until the middle of the nineties and favorable there on (NOCE et al., 2006). In other areas of the economy, this procedure is also considered economically valid to describe the risk-return relationship as is the case of oleiculture (MOTTA et al., 2005).

The use of $C V$ is recommended as dispersion measure among series of different distribution (SPIEGEL, 1985). Being obtained through the quotient between the standard deviation and the arithmetic mean of the series, according to formula that proceeds:

$$
C V=\frac{s}{\bar{x}} 100
$$

where:

$C V=$ variation coefficient;

$s=$ standard deviation;

$\bar{x}=$ arithmetic mean .

$T G C$ 's were calculated and were statistically determined by linear regression of tendency represented by the following expression:

$$
\log Y=a+b T
$$

In that:

$Y=$ corrected price in $R \$$;

$a=$ constant of the regression;

$b=$ coefficient of the regression; and

$T=$ tendency.

Cerne, Lavras, v. 16, n. 2, p. 199-207 abr./jun. 2010 
For values of " $b$ " significantly different from zero, the geometric rate of growth was calculated by the formula:

$$
\begin{aligned}
& A n t \log b=1+T G C / 100 \\
& T G C=(A n t \log b-1) \times 100
\end{aligned}
$$

$T G C$ expresses the growth of the series, in percentage, per period of analysis. Levels of significance of the estimated parameter " $b$ ", appraised according to " $t$ " test, superior to $10 \%$, increase the probability of error in affirming that $T G C$ is statistically different from zero. Therefore, only estimated values significant at $5 \%$ of probability, were considered.

\section{RESULTS AND DISCUSSION}

\subsection{Price behavior}

The adjusted prices of the $\mathrm{m}^{3}$ of the Ipê sawn wood, Jatobá, Maçaranduba, Angelim Pedra, Angelim Vermelho and Cumaru proved growth during the period of January 2003 to December 2007, so with positive returns. The Ipê presented a higher price than other species, while Jatobá and Cumaru price series proved relatively similar behavior with intermediate values. The representative price series of Angelim Pedra, Angelim Vermelho e Maçaranduba also presented relatively similar behavior with lower price than the other species (Figure 1).
It was noted that in 2003 the Cumaru prices presented a distinct behavior from the group species analyzed in October, presenting price increase while the others reduced its values (Figure 2)

In 2004, Jatobá presented differentiated behavior of other specimens in July and December with price reductions toward the increase value associated with the others, and also being the only specie to break the pattern in 2005, with price reduction in July. While in 2004, the prices showed increase throughout the year, with the exception of June. In 2005 it was noticed a price growth break only in March, in addition to the exceptions cited before (Figures 3 and 4).

During the year 2006 Cumaru was the only specie to present a distinct price behavior, with reduction in February. The prices constancy predominated in 2006, being broken by price increases in October, in general (Figure 5).

During the year 2007 the Jatobá breaks the pattern behavior of the group in July and August with successive reductions in price. Among the analyzed species only Jatobá and Cumaru had a different behavior of prices in the species group. In 2007 price growth has been observed with intensification in September for all species, except the exceptions cited (Figure 6).

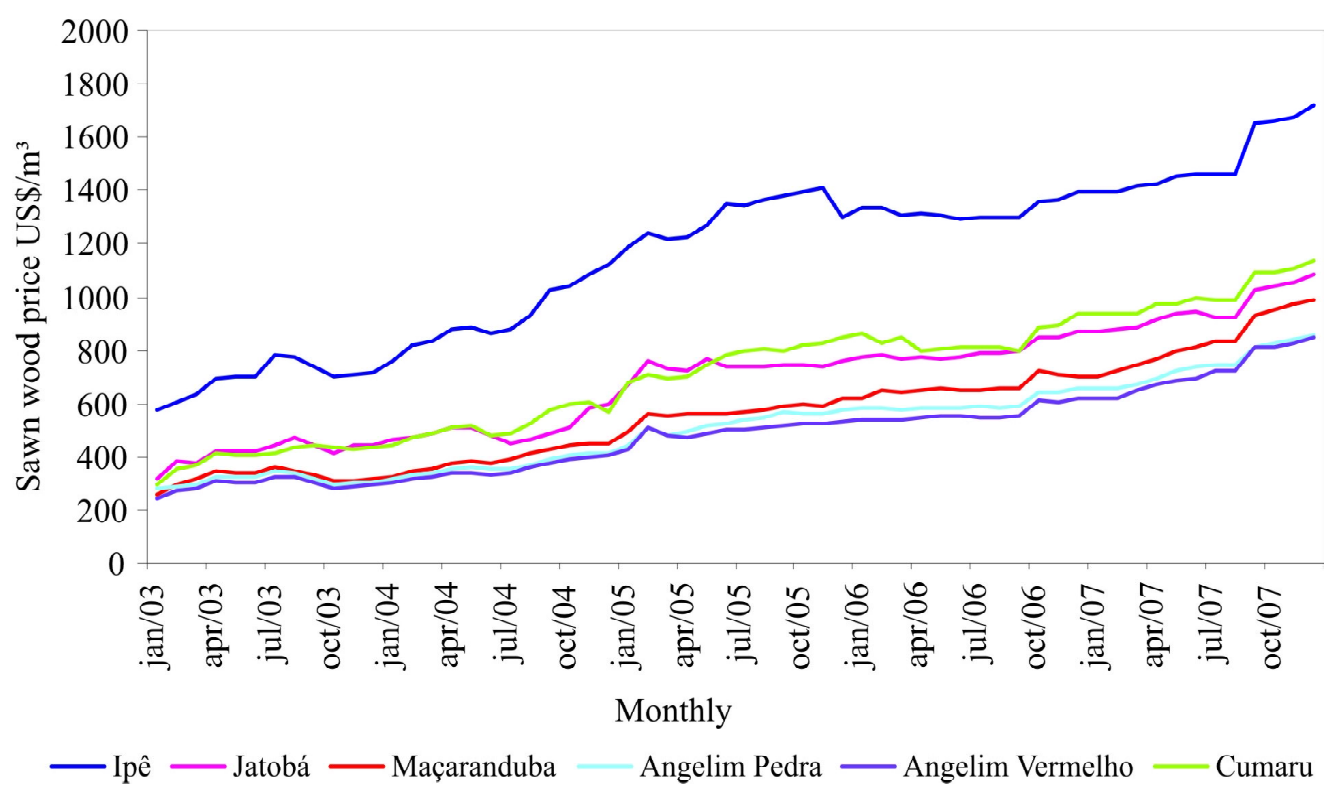

Figure 1 - Behavior of the monthly real price of boards of native species wood in Pará, from 2003 to 2007.

Figura 1 - Comportamento do preço mensal real de pranchas de madeira de espécies nativas no Pará de 2003 a 2007.

Cerne, Lavras, v. 16, n. 2, p. 199-207, abr./jun. 2010 


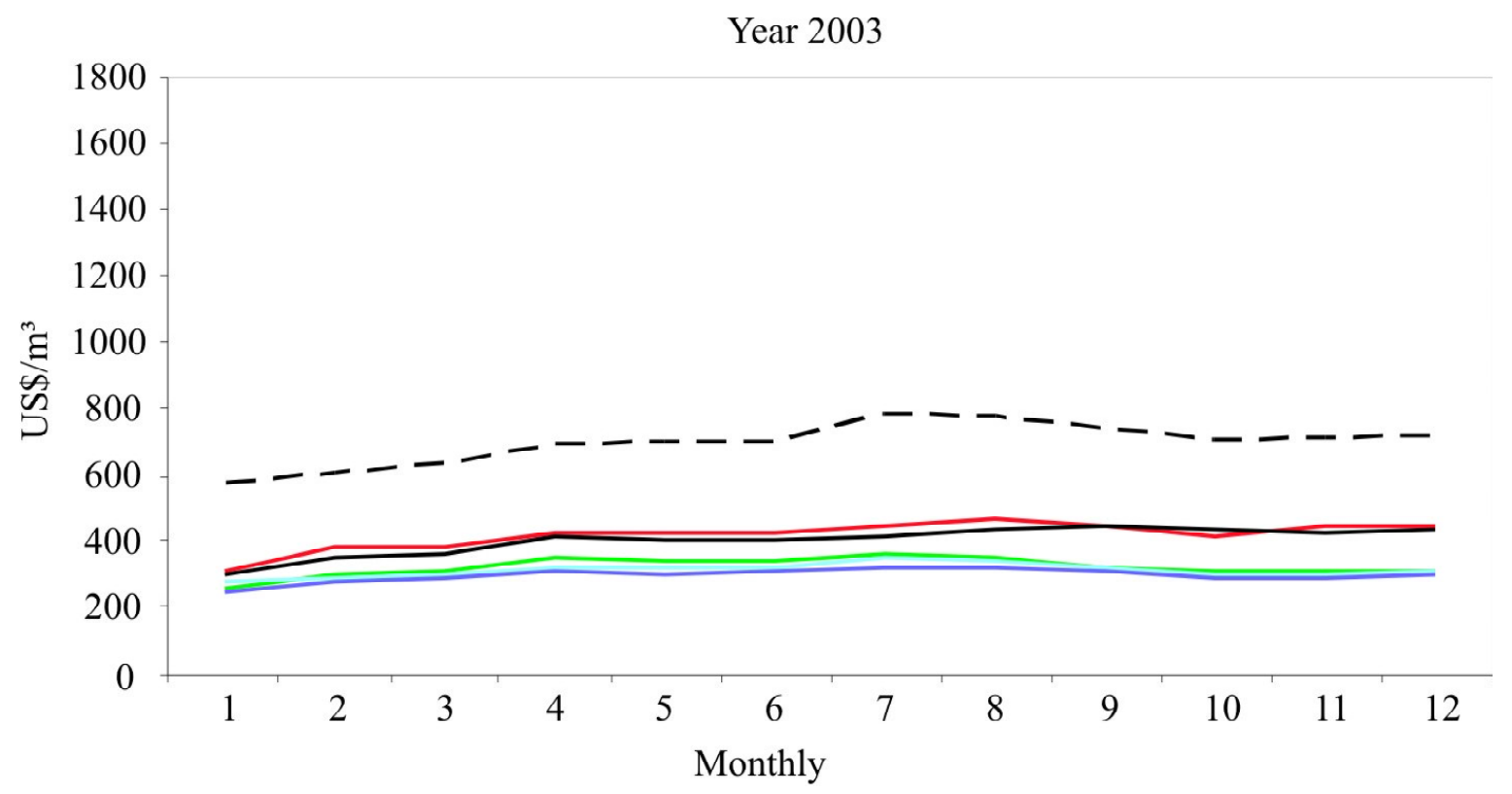

- - Ipê — Jatobá — Maçaranduba —_ Angelim Pedra — Angelim Vermelho — Cumaru

Figure 2 - Behavior of monthly real price of Pará native species sawn wood in 2003.

Figura 2 - Comportamento do preço mensal real de madeira serrada de espécies nativas no Pará no ano de 2003.

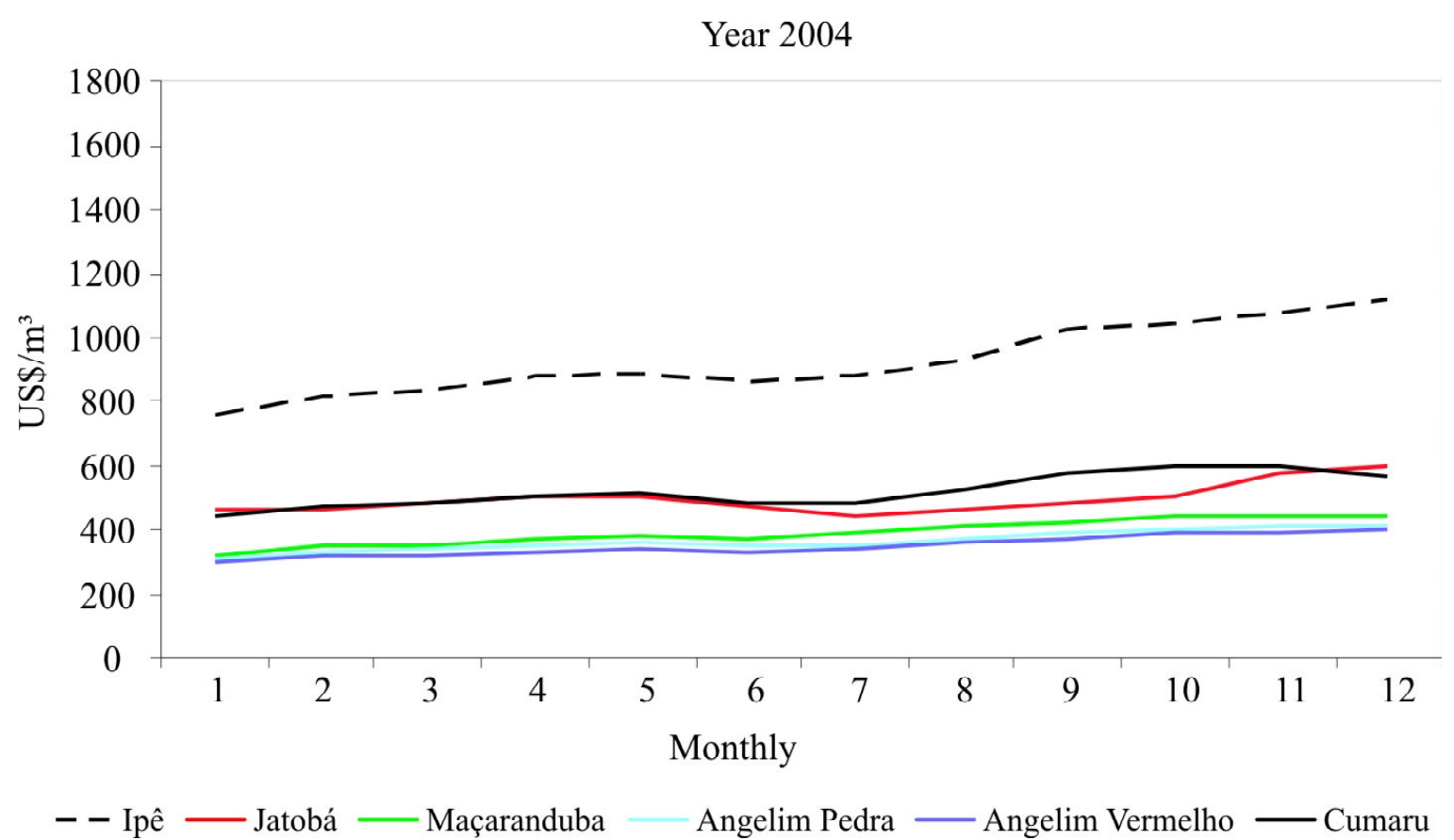

Figure 3 - Behavior of monthly real price of Pará native species sawn wood in 2004.

Figura 3 - Comportamento do preço mensal real de madeira serrada de espécies nativas no Pará no ano de 2004.

Cerne, Lavras, v. 16, n. 2, p. 199-207 abr./jun. 2010 


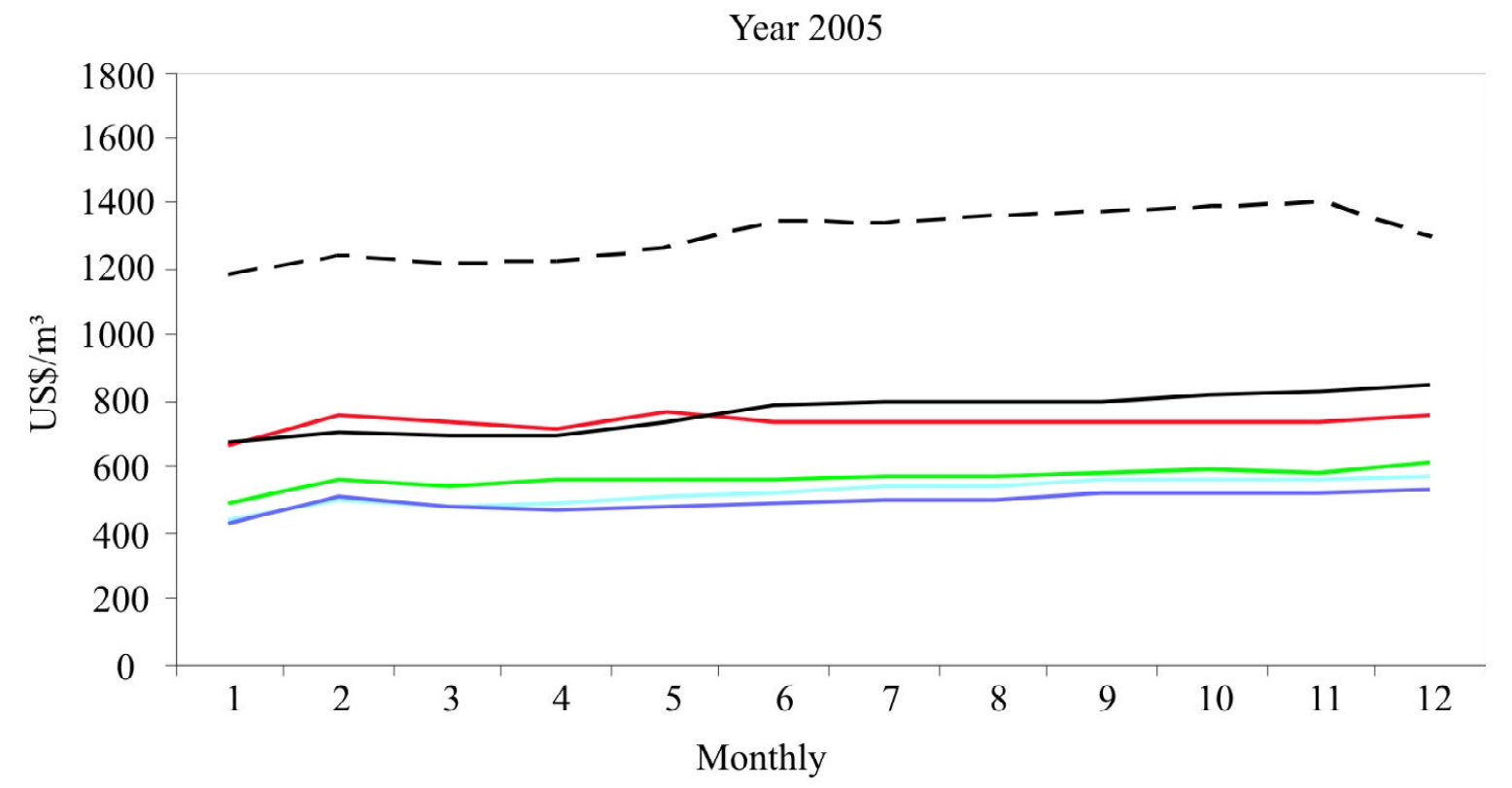

- - Ipê — Jatobá — Maçaranduba ——Angelim Pedra — Angelim Vermelho — Cumaru

Figure 4 - Behavior of monthly real price of Pará native species sawn wood in 2005.

Figura 4 - Comportamento do preço mensal real de madeira serrada de espécies nativas no Pará no ano de 2005.

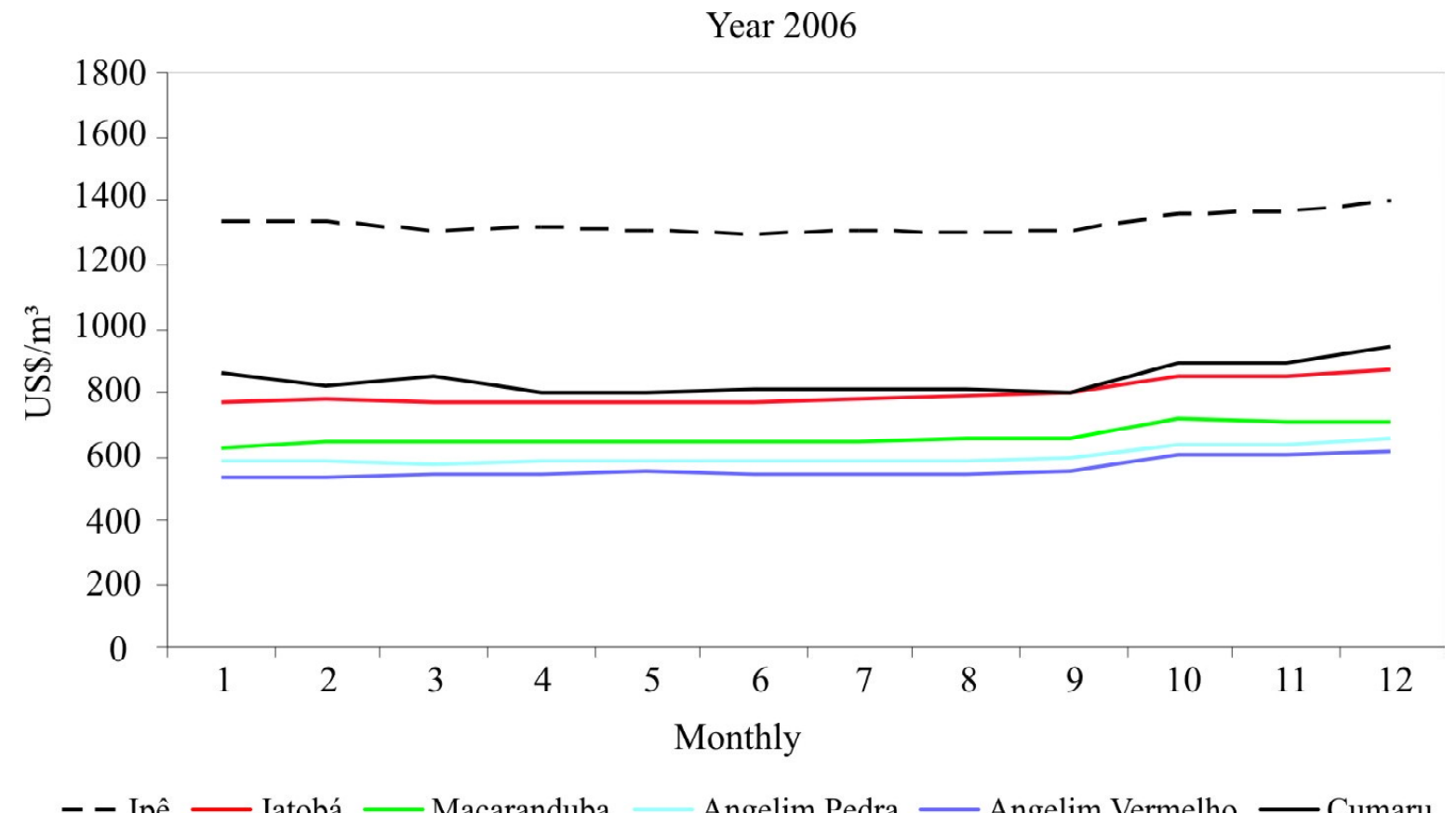

Figure 5 - Behavior of monthly real price of Pará native species sawn wood in 2006.

Figura 5 - Comportamento do preço mensal real de madeira serrada de espécies nativas no Pará no ano de 2006. 


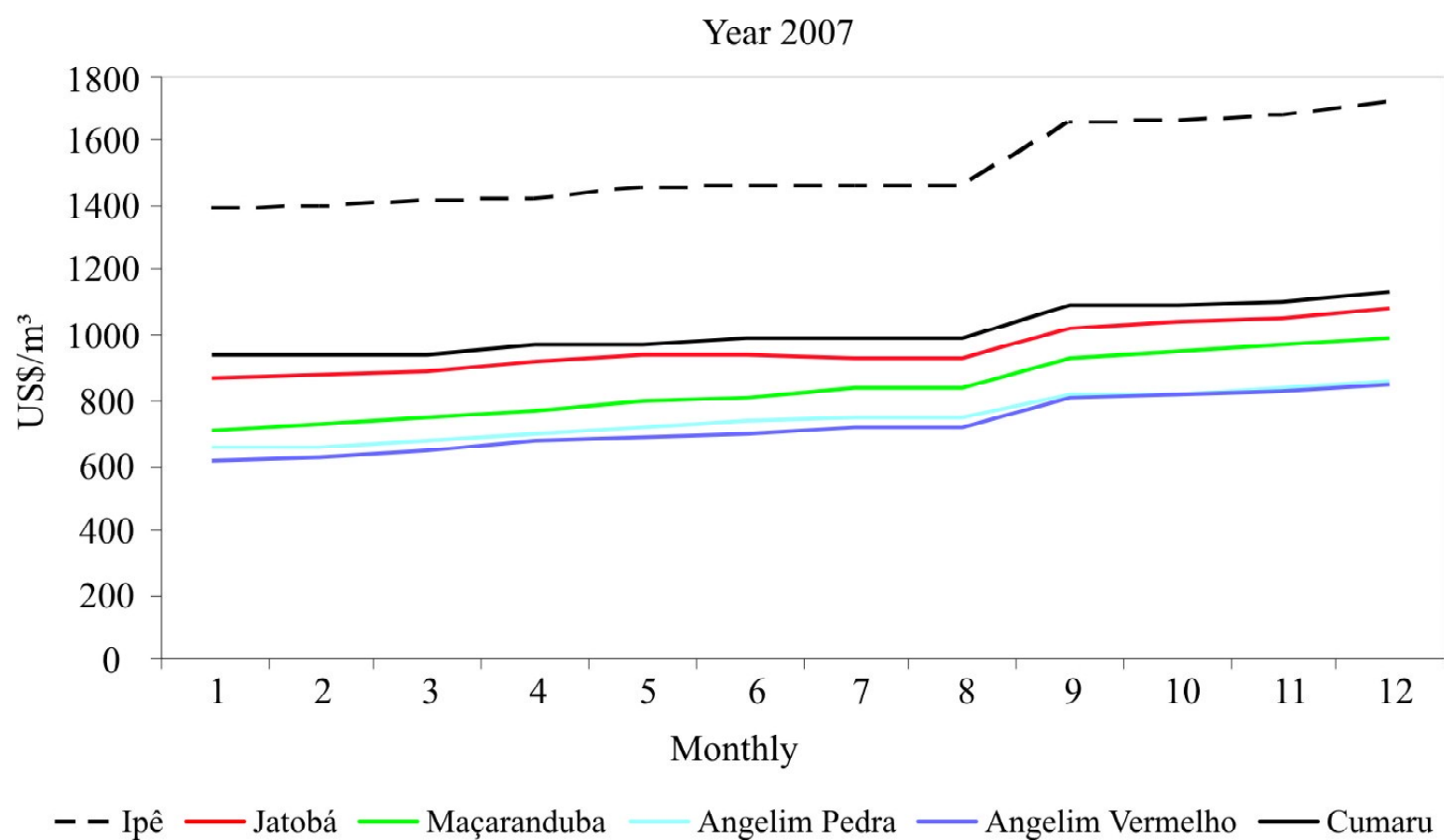

Figure 6 - Behavior of monthly real price of Pará native species sawn wood in 2007.

Figura 6 - Comportamento do preço mensal real de madeira serrada de espécies nativas no Pará no ano de 2007.

It was noticed that although the prices of different species behave with certain similarity, graphically they repeated annual behavior. It was possible to observe that Cumaru presented intermediate price with the lowest fluctuations of values, so that this specie has proved to have a potential for substitution in relation to the others.

\subsection{Relationship among species}

The estimate of the risk-return relationship, considering January 2003 to December 2007 period as a whole, demonstrates that both for the level of associated risk $(C V)$ as for the expected return $(T G C)$ increased from Angelim Pedra to Angelim Vermelho, Maçaranduba, Ipê and Cumaru successively. It stands out that Jatobá presents risk level similar to Maçaranduba, with higher returns and, yet, expectation of higher return and lower risk than those of Ipê. This turns Jatobá more attractive in relation to Maçaranduba and Ipê, both in risk and return terms and, consequently, more susceptible to exploitation (Figure 7).

During 2003, returns and risks increased from Angelim Pedra to Angelim Vermelho, Ipê, Jatobá and Cumaru successively. Maçaranduba presented higher risk than Angelim Vermelho and expectation of lower return, presenting a risk level close to Ipê, that presents a expected return extremely inferior. The risk and return level increased from Angelim Pedra, Angelim Vermelho, Maçaranduba and Ipê, during 2004. Angelim Vermelho and Angelim Pedra presented higher return and smaller risk, as compared to Cumaru and Jatobá, respectively, standing out in relation to the economic attractiveness. The risk and the return increased in 2005 from Jatobá to Angelim Vermelho, Ipê, Angelim Pedra and Cumaru, successively. It was observed that Maçaranduba presented return similar to that observed for Angelim Vermelho and Ipê, but with smaller risk. Cumaru presented, in 2006, the largest risk level and lower return than Ipê. Both risk and return intensifies departing from Ipê to Angelim Pedra, Maçaranduba, Jatobá and Angelim Vermelho. It stands out that Angelim Pedra and Maçaranduba were shown in the same risk and return level. During 2007, it was observed that risk and return increased departing from Cumaru to Jatobá, Ipê, Angelim Pedra, Angelim Vermelho and Maçaranduba (Figure 8).

The pattern of coherence of the risk-return relationship was broken, in an annual perspective, by Maçaranduba, in 2003, by Jatobá and Cumaru, in 2004 and 2006, and by Angelim Vermelho, in 2005, which presented lower returns and higher risk as compared to the other species.

Cerne, Lavras, v. 16, n. 2, p. 199-207 abr./jun. 2010 


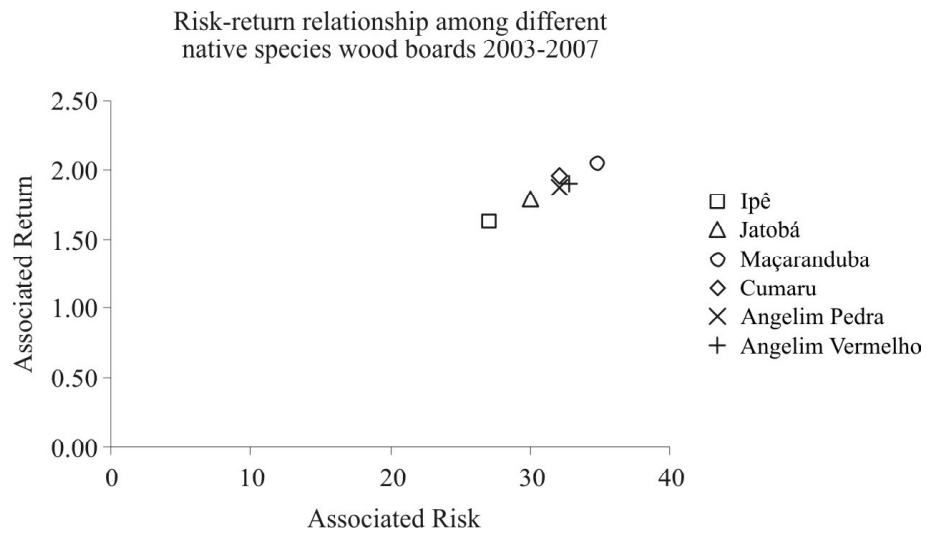

Figure 7 - Risk-return relationship among species from 2003 to 2007.

Figura 7 - Relação risco/retorno entre espécies de 2003 a 2007.
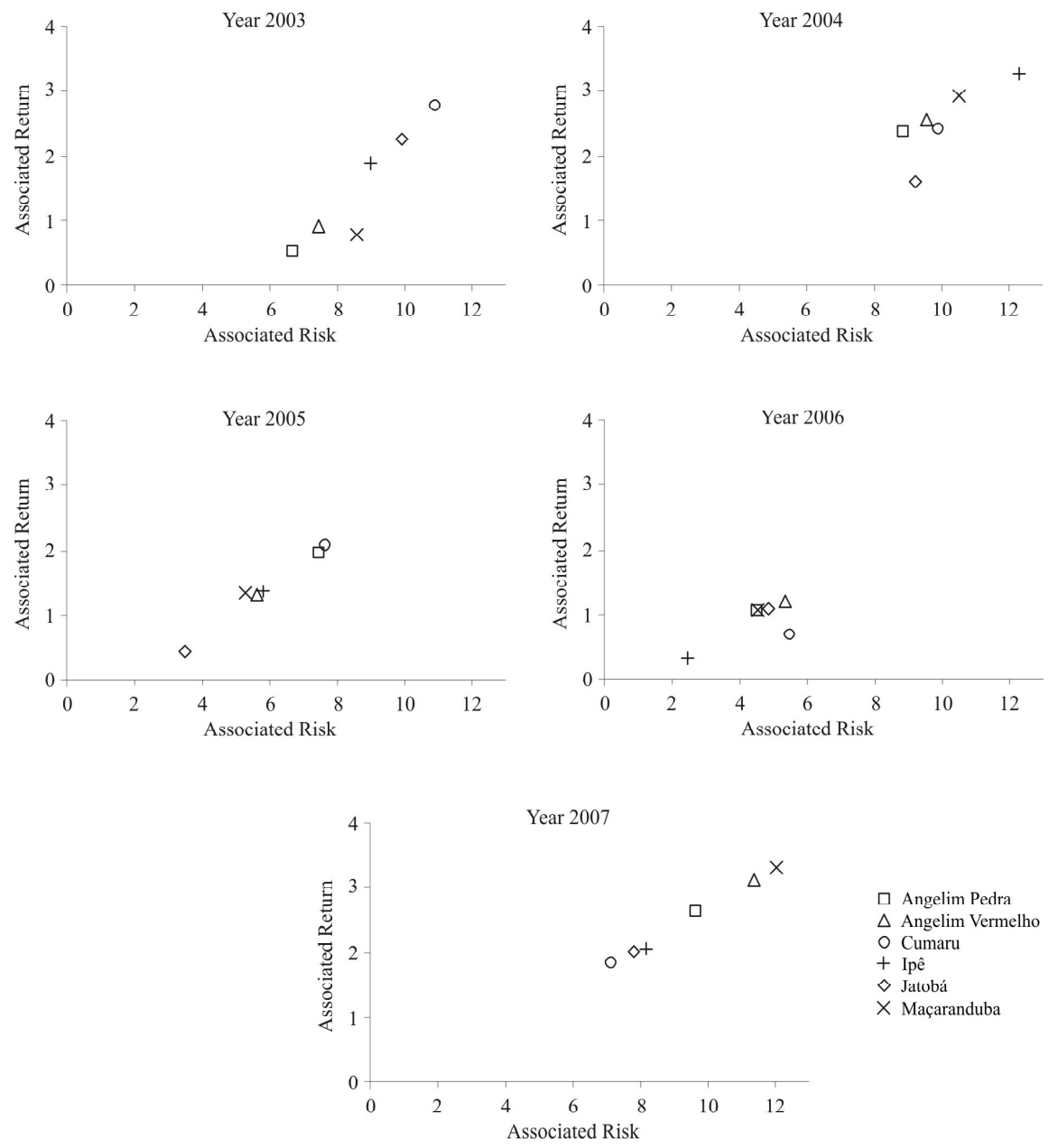

Figure 8 - Risk-return relationship among species from 2003 to 2007 year by year.

Figura 8-Relação risco retorno entre as espécies de 2003 a 2007 ano a ano. 
Angelim Vermelho has shown, therefore, more attractive than Maçaranduba, in 2003; Angelim Pedra and Angelim Vermelho than Jatobá and Cumaru, respectively, in 2004; Maçaranduba than Angelim Vermelho, in 2005; Angelim Pedra and Maçaranduba than Jatobá and Cumaru, in 2006, in terms of the risk-return relationship.

\subsection{Evolution of the relationship of each species}

Ipê presented substantial return and risk increase, from 2003 to 2004. However, in 2005, both for risk and for return, it was observed inferior levels than those observed in 2003, similar pattern was also observes in 2006. In 2007, however, risk and return increase, but with higher return and lower risk levels, as those reached in 2003. Jatobá had its risk and associated return successively reduced in 2003, 2004 and
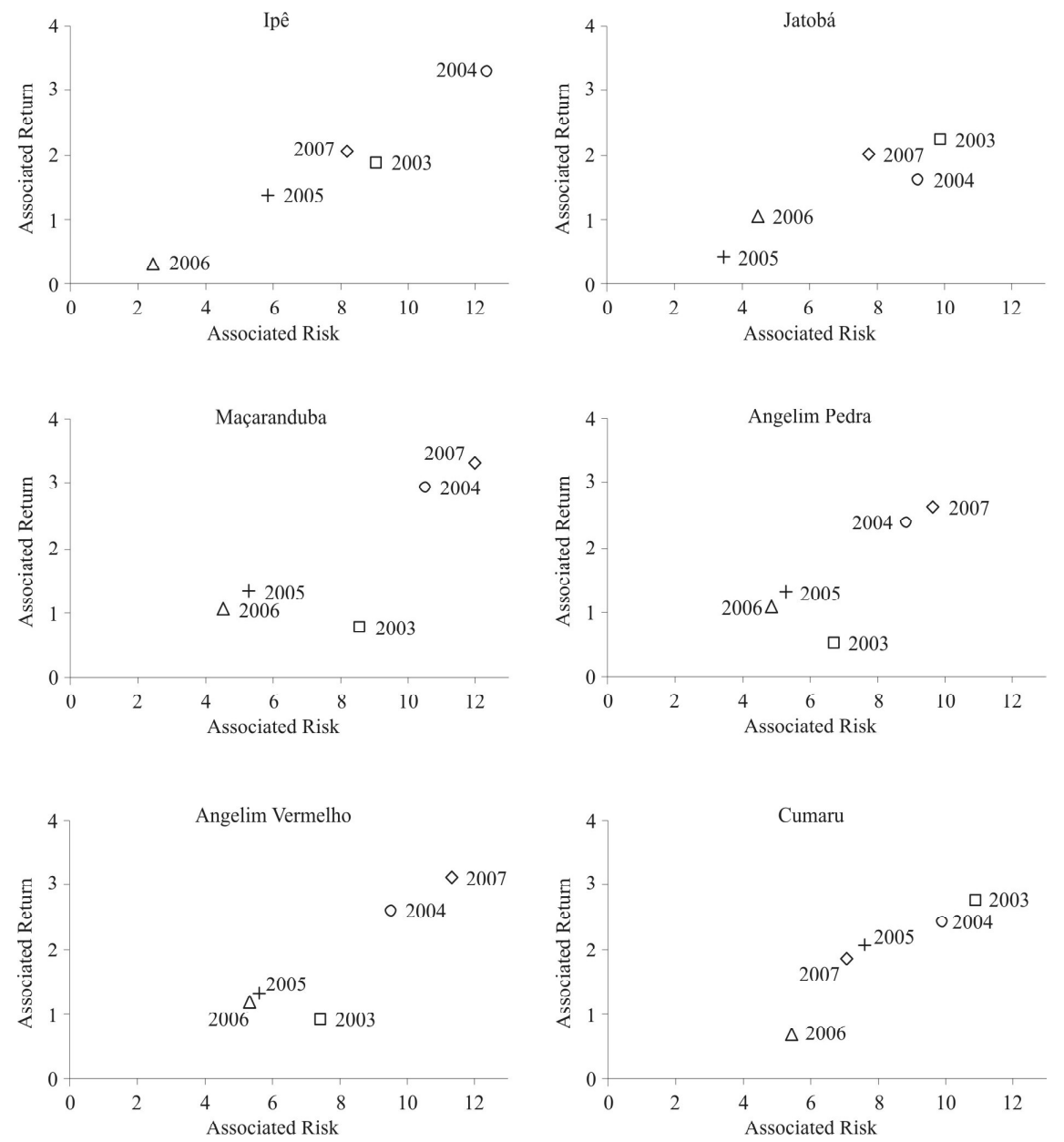

Figure 9 - Evolution of risk-return relationship of each species from 2003 to 2007.

Figura 9 - Evolução da relação risco retorno de cada espécie de 2003 a 2007.

Cerne, Lavras, v. 16, n. 2, p. 199-207 abr./jun. 2010 presented risk and return increase in 2007 (Figure 9). Vermelho, increased risks, as much as the return.

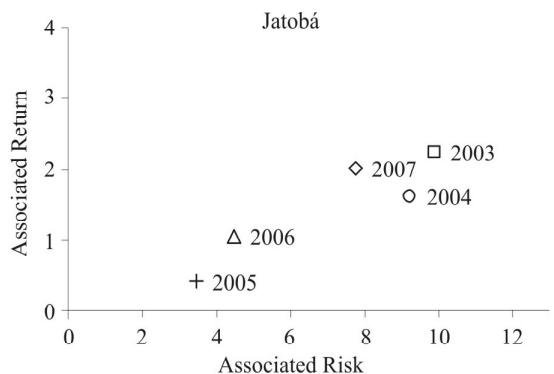

2005, but experienced successive increases in 2005, 2006 and 2007. The evolution of the risk-return relationship were similar for Maçaranduba, Angelim Pedra and Angelim Vermelho, presenting risk and return increase, from 2003 to 2004, and decrease in 2005 and 2006, but rose again to the observed maximum level of risk and return of 2007. It stands out that the estimated return was higher than that observed in 2003, with lower risk. Cumaru presented successive risk and return reduction in 2003, as compared to 2004, 2005 and 2006, but

During the analyzed period, Ipé became more attractive, presenting lower risk level and higher return in 2007, in relation to that observed in 2003. Jatobá and Cumaru reduced the associated risks as much as the estimated return. Maçaranduba, Angelim Pedra and Angelim 


\section{CONCLUSIONS}

In the conditions that this study was accomplished, it could be concluded that:

- Ipê, Jatobá, Maçaranduba, Angelim Pedra, Angelim Vermelho and Cumaru boards prices floated relatively in a similar way. This pattern is broken occasionally by Jatobá and Cumaru prices;

- Jatobá stands out in attractiveness terms, considering the whole analyzed period, by presenting expectations of higher return and lower risks, as compared to those of Maçaranduba and Ipê. The other species presented a coherent relationship. i.e., higher return associated to higher risk;

- under annual temporary horizon, Angelim Vermelho and Maçaranduba stood, out in relation to the attractiveness, besides Ipê, that became more attractive.

\section{AKNOWLEDGEMENTS}

To the Coordination of Superior Level Personnel Improvement (CAPES-Coordenação de Aperfeiçoamento de Pessoal de Nível Superior).

\section{BIBLIOGRAPHICAL REFERENCES}

BURATTO, M. V. Construção e avaliação de um modelo de simulação de monte carlo para analisar a capacidade de pagamento das empresas em financiamentos de longo prazo. 2005. 141 p. Dissertação (Mestrado) - Universidade Federal do Rio Grande do Sul, Porto Alegre, 2005.

CASTRO, R. R.; SILVA, M. L.; LEITE, H. G.; OLIVEIRA, M. L. R. Rentabilidade econômica e risco na produção de carvão vegetal. Revista Cerne, Lavras, v. 13, n. 4, p. 353-359, out./dez. 2007.

CENTRO DE ESTUDOS AVANÇADOS EM ECONOMIA APLICADA. Disponível em: 4 http://www.cepea. esalq.usp.br/ >. Acesso em: 25 maio 2008.

CONTADOR, C. R.; SILVA JUNIOR, L. C. A. Inflação, preços relativos e risco na agricultura: algumas notas. In: CONGRESSO BRASILEIRO DE ECONOMIA E SOCIOLOGIA RURAL, 30., 1992, Rio de Janeiro. Anais... Brasília: SOBER, 1992. p. 27-34.
GITMAN, L. J. Princípios de administração financeira. 10. ed. São Paulo: Habra, 2004. 776 p.

INSTITUTO DE PESQUISA ECONÔMICA APLICADA. Disponivel em: ${ }_{1}<\mathrm{h}$ http://www.ipeadata ipeadata?1118993484>. Acesso em: 25 maio 2008.

LEMGRUBER, E. F.; OHANIAN, G. O Modelo de projeção de volatilidade do RiskMetricsTM e a hipótese de distribuição normal condicional para alguns fatores de risco do Brasil. In: ENANPAD, 21., 1997, Rio das Pedras. Anais... Rio das Pedras: ANPAD, 1997. CD-ROM.

MOTA, J. H.; NOCE, R.; YURI, J. E.; RESENDE, G. M.; SOUZA, R. J. Análise da evolução da produção e relação riscoretorno para a cultura do alho, no Brasil e regiões: 1991 a 2000. Horticultura Brasileira, Brasília, v. 23, n. 2, p .238241, 2005a.

NOCE, R.; CARVALHO, R. M. M. A.; SOARES, T. S.; SILVA, M. L. Desempenho do Brasil nas exportações de madeira serrada. Revista Árvore, Viçosa, v. 27, n. 5, p. 695-700, 2003.

NOCE, R.; SILVA, M. L.; CARVALHO, R. M. M. A.; SOARES, T. S. Concentração das exportações no mercado internacional de madeira serrada. Revista Árvore, Viçosa, v. 29, n. 3, p. 431-437, 2005.

NOCE, R.; SILVA, M. L.; OLIVEIRA, J. M.; JACOVINE, L. A. G.; SOARES, N. S. Relação de risco e retorno e tendência da produção brasileira de borracha natural. In: ALVARENGA, A. P.; ROSADO, P. L.; CARMO, C. A. F. S.; TÔSTO, S. G. Seringueira aspectos econômicos sociais e perspectivas para o seu fortalecimento. Viçosa, MG: Suprema, 2006. p. 165-180, 180 p.

NOCE, R.; SILVA, M. L.; SOARES, T. S.; CARVALHO, R. M. M. A. Análise de risco e retorno do setor florestal: produtos da madeira. Revista Árvore, Viçosa, v. 29, n. 1, p. 77-84, 2005 b.

SPIEGEL, M. R. Estatística. São Paulo: McGraw-Hill, 1985. $454 \mathrm{p}$. 
